\title{
OBSERVATIONS ON DISTICHOPHYLLUM PROCUMBENS MITT. A PLEUROCARPOUS AND SECONDARILY-AQUATIC MOSS NEW TO NIGERIA
}

\author{
${ }^{1}$ Egunyomi A. and ${ }^{2 *}$ Oyesiku O.O. \\ ${ }^{1}$ Department of Botany, University of Ibadan, Ibadan. Email:aegunyomi200@yahoo.com \\ ${ }^{2 *}$ Department of Plant Science, Olabisi Onabanjo University,Ago-Iwoye \\ *Correspondence author: oyesiku.olubukunola@oouagoiwoye.edu.ng \\ (Received: 24th March, 2017; Accepted: 30th May, 2017)
}

\section{ABSTRACT}

\begin{abstract}
A pleurocarpous moss found to be anchored and thriving on rock in an aquatic habitat at Ago-Iwoye in Ogun State, Nigeria, was identified as Distichophyllum procumbens Mitt. and described. As the moss had been reported to be corticolous and terricolous in Ghana and Cameroon, this is the first report of its occurrence in Nigeria and of its aquatic nature in Africa. Based on field study and microscopic examination of the morphological features of the moss, observations were made on its structural adaptations to an aquatic habitat. The rheophilous adaptations include, shoots turning reddish brown when exposed in the dry season, "stem leaf" having border and strong costa, aperistomate capsule splitting into valves for spore discharge, and the presence of rhizoids only at the base of the stem without any tomentum.
\end{abstract}

Key words: Aperistomate, aquatic, Distichophyllum procumbens, moss, rheophilous

\section{INTRODUCTION}

While on a bryological forays in Ago-Iwoye, Ogun State, Nigeria, a large population of a moss anchored and thriving on rock under a fast flowing water current was encountered and samples collected, although the majority of bryophytes are humid-loving, essentially terrestrial plants, few are true aquatic plants.

Aquatic bryophytes have been reported from various parts of the world. Brachythecium rivulare and Eurynchium riparioides occur in Wales, United Kingdom (Mclean and Jones, 1975), Cratoneuron filicinum from Canada (Richardson, 1981), Fontinalis novae-angliae and F. dalecarlica from USA (Glime, 1971). The only aquatic bryophyte known to Africa is the moss Fontinalis antipyretica. This species was introduced into a South African stream with a view that it would harbour shrimps and larvae for trout food (Glime, 1971). All of the foregoing examples are obligate aquatic mosses. As an adaptive feature, the moss Hydropogon fontinaloides found in the Amazon basin, hangs from trees during the dry season and in the wet season, floats in the water (Magdefrau, 1973).

The unexpected discovery of a moss anchored and thriving under flowing water raised a few questions. Could the moss be one of the obligate aquatic mosses known to Science? Since no aquatic moss had been reported in the literature from Nigeria, could the present finding be a new record? After rigorous microscopic examination of the plant material with sporophytes and with the aid of texts as well as monographs on mosses (Buck and Goffinet 2000, Ingold 1959, Matteri 1975, Miller 1971, O'Shea 2006, Richards and Edwards 1972, Richardson 1981, Vitt 1981 and Vitt and Glime 1984) the moss was identified as Distichophyllum procumbens Mitt. This paper reports the observations made on the morphological features of $D$. procumbens, which appears to show secondary adaptation to aquatic habitat.

\section{Description of Distichophyllumprocumbens Mitt.}

Plants in lax tufts, small, procumbent and complanate; non-dichotomously branched. "Stems" thin $1.5-4.0 \mathrm{~cm}$ long, with 3 rows of "leaves". (2 laterals and 1 dorsal). Lateral leaves $1.43-2.11 \mathrm{~mm}$ long x $0.56-0.68 \mathrm{~mm}$ wide. Dorsal leaves, $0.87-1.15 \mathrm{~mm} \times 0.55-0.56 \mathrm{~mm}$. Leaves are symmetrical on both sides of costa, ovate-lanceolate from a narrow base, leaf apex obtuse to acute. Costa strongly defined, single, ceasing well below the leaf apex and it is well above the middle of lamina. Leaf margin is entire, narrowly bordered with a single row of linear cells. Areolation shows round thin-walled cells; apical and median cells rectangular-oval, and basal cells being rectangular-rhomboidal (Fig. 1). Rhizoids 
occurring scanty only at the base of the stem. Sporophytes upright, perichaetial leaves concave with costa. Seta flexuose and long $(12-34 \mathrm{~mm})$, capsule $(1.14-1.67 \mathrm{~mm}$ long, $0.62-0.87 \mathrm{~mm}$ wide) small, erect and symmetrical, conical, non- operculate, aperistomate, with distinct apophysis. Capsule wall with lines of dehiscence for spore release. Spore barrels $1.70 \mathrm{~mm}$ - $2.62 \mathrm{~mm}$ x 90 $178 \mathrm{~mm}$ with floater jackets.
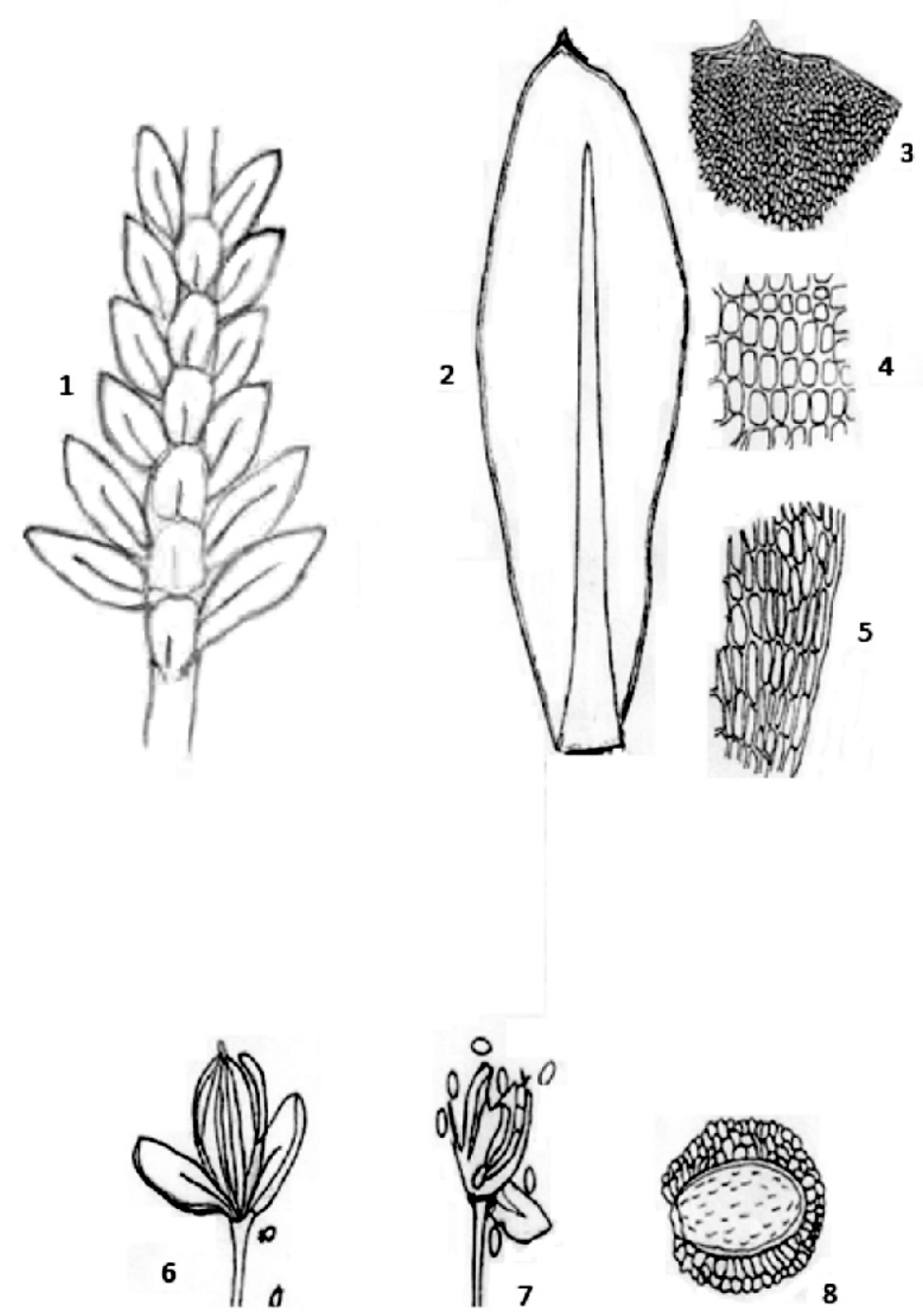

Figure 1: Distichopbyllum procumbens Mitt. 1= shoot adaxial view (X10), $2=$ lateral leaf (X60), 3 = leaf apex areolation (X180), $4=$ median leaf areolation (X180), $5=$ basal leaf areolation $(X 180), 6=$ mature sporophyte $(\mathrm{X} 60), 7=$ dehisced sporophyte $(\mathrm{X} 60), 8=$ spore barrel with floater jacket $(\mathrm{X} 540)$

Distichophyllum procumbens formerly in the family Hookeriaceae was moved with five other genera into a new family Distichophyllaceae by Miller (1971). In spite of this revision, Matteri (1975) also revised the Hookeriaceae family, recognizing two subfamilies, Distichophylloideae and Hypnelloideae. The Distichophylloideae in her treatment comprised Distichophyllum, Eriopus and Pterygophyllum. Although, Matteri (1975) reduced
D. procumbens to the synonymy of Distichophyllum eremitae (Jaeg.) Par. This study has shown that $D$. procumbens differs from $D$. eremitae. The latter which is robust, having long seta, the leaves being concave and apiculate. Additionally, the stem of $D$. eremitae has 4-5 rows of leaves while $D$. procumbens has only 3. (Figure1).These differences show that $D$. procumbens cannot be conspecific with D. eremitae. 
According to O'Shea (2006), D. procumbens listed as a distinct species has been recorded from Ghana and Cameroons. Since there has been no previous report in the literature, the present finding is a new record of the moss in Nigeria. Richards and Edwards (1972) reported that the Ghana collections of $D$. procumbens, were made from rotten log in a moist valley, and from stems of tree ferns. In the Cameroons Mountain (1,145 m), the moss samples were collected from tree roots, humus soil in a shady moist gulley and on fallen fern trunk. Based on these records, the moss has been epixylic, corticolous, terricolous, saxicolous and aquatic. Thus, the present finding is the first report of its secondary adaptation to aquatic habitat in Africa.

\section{Description of the Ago-Iwoye aquatic site}

The habitat of $D$. procumbens is Omee river (Lat $6.93-6.99 \mathrm{~N}$, Long $3.79-3.92 \mathrm{E}$, altitude $19-172$ $\mathrm{m})$ in the vicinity of Olabisi Onabanjo University, Ago-Iwoye, Ogun State, Nigeria (Figure 2). The vegetation of Omee river bank at the time of collection (November - March) was dominated by Albizia spp. and Bambusa vulgaris. Along the Omee course, branches of trees irregularly overhang the river creating partial shade. The width of the river varied from $8-20 \mathrm{~m}$ and $4-8 \mathrm{~m}$ deep. Expectedly, the river flow was higher in the rainy than the dry season. However, during the dry season, the river flow speed was high along the course of the river where rock boulders were found. The submerged rock boulders constituted the major habitat of $D$. procumbens (Figure 2).

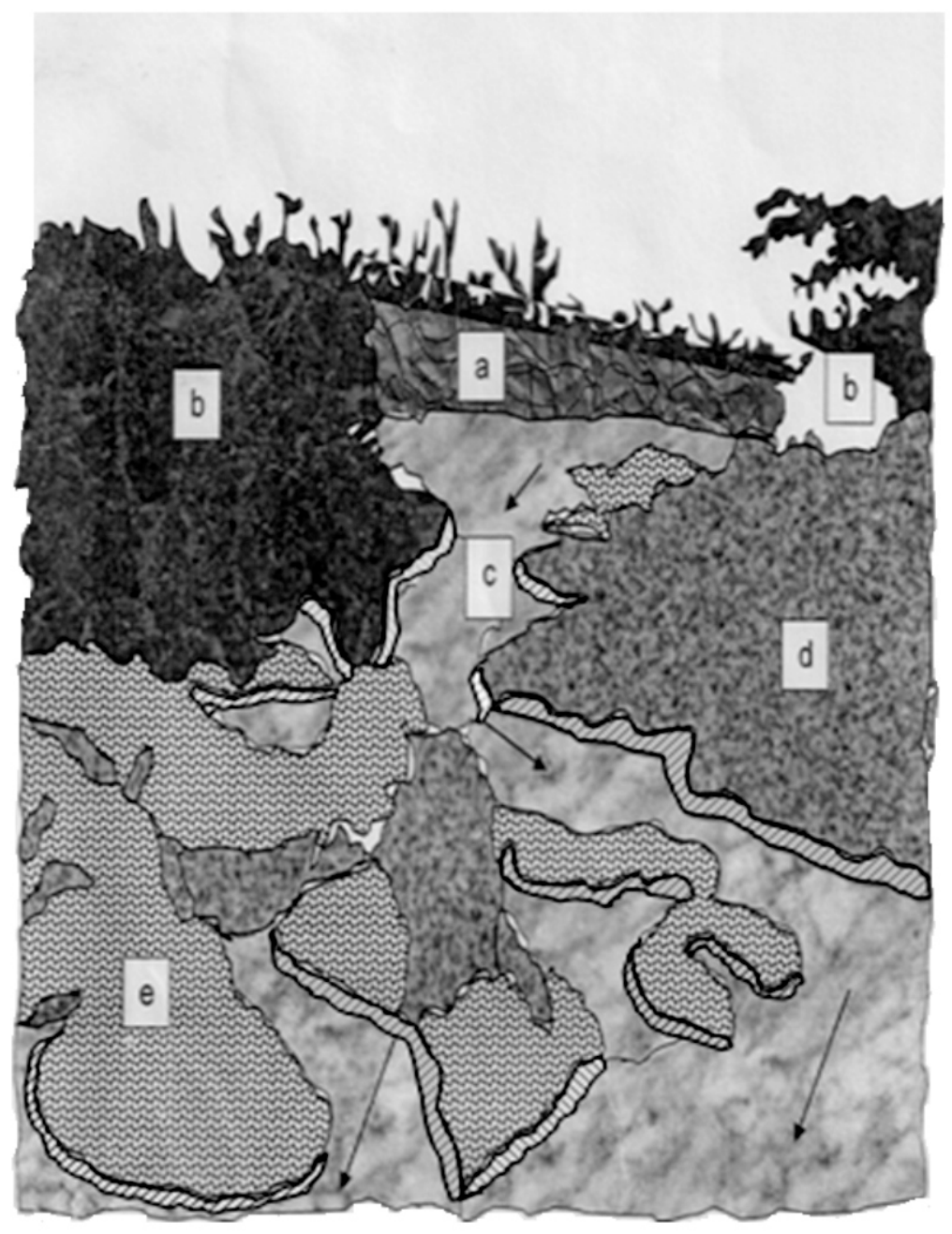

Figure 2: Three dimensional natural habitat of Distichophyllum procumbens. (a) River bank at higher depth (b), Tree canopy along the river bank with branches hanging above the river (c), Fast flowing river (1.2+ $0.06 \mathrm{~ms}^{-1}$ ) over rock boulders in the direction of the arrow (d), Exposed bare granite rock (e), Exposed granite rock covered with $D$. procumbens Lat. $6.9207^{\circ} \mathrm{N}$, Long. $3.7910^{\circ}$ E. alt. $20 \mathrm{~m}$ 
Adaptation of $D$. procumbens to aquatic habitat During the rainy season (April - October) when the water level became relatively high, the gametophytes and sporophytes of the pleurocarpous moss thrived on submerged granite rock surfaces. However, in the dry season (November-March) the water level dropped and submerged rocks and woods appeared above the water surface, exposing the populations of $D$. procumbens to scorching heat and light of the sun. That the moss could tolerate both totally submersed and totally dry conditions makes it a facultative aquatic. According to Vitt and Glime (1984), facultative aquatics are mostly rheophilous i.e. usually found in flowing water such as Omee river.

In the present study, it was observed that relatively larger populations of $D$. procumbens were encountered in fast-flowing rather than slowflowing water. As reported by Glime and Raeymackers (1987), the aquatic pleurocarp, Fontinalis species had significantly more branches in flowing water than in standing pool condition. The absence of rhizoids in contact points of $D$. procumbens shoots with rock surface may probably be due to production of adhesive substance by the Golgi bodies, as has been well documented for the settling of spores of several major groups of algae (Braten, 1975, Callow and Evans, 1974). Glime et al. (1979) reported that a mechanism for attachment of aquatic mosses to rocks is by gluing of the plants to rocks when water levels recede. They observed that alternate wetting and drying caused Hygroamblystegium fluviatile, an aquatic moss, to be cemented to rocks.

As observed in the field, shoots of D. procumbens exposed to the rambling of weather in the dry season, became reddish-brown colour while parts still submersed remained green. Colour variation of red, brown, black, dark-green is a rheophilous adaptation (Vitt and Glime, 1984).

The shoots of $D$. procumbens were observed to always adhere to rock surface substratum despite high flow of water. Glime and Raeymaekers (1987) reported that the ability of a stream moss to remain attached to the substratum during periods of rapid flow is primarily a function of the rhizoids. This view seems not to hold for $D$. procumbens on which rhizoids occurred only at the base of the stem and not on any other part of the gametophyte or its stoloniferous branches.

This rheophilous adaptation has also been reported in Fontinalis novae-angliae by Glime (1980). Odu (1979) has shown that the sites of origin of rhizoids of pleurocarpous mosses are related to the habitat and phylogeny of the species.

As shown in figure 1, lateral "leaves"of $D$. procumbens are characterised by leaf borders and strong costae. Glime and Vitt (1987) ascribed such features to be modifications in rheophytes for strengthening the leaf structures and protection against strong water current.

In the dry season, mature capsules of the sporophytes dehisce vertically into four valves, thus releasing spore barrels, which have floater jackets (Figure 1). Discharged spore barrels may be dispersed by wind or drop back into water and eventually become deposited on rock surface. Vitt (1981) recognized a group of moss species such as Fontinalis, Wardia and Scouleria, which have a tendency to produce certain types of sporophytes are adapted to the aquatic habitat. Their sporophytes have reduced or no peristomes and ovate or oblong immersed capsules. $D$. procumbens appears to fall into this group, having submerged sporophytes with aperistomate capsules, and spore barrels with floater jackets. Ingold (1959) observed that the survival of spores being liberated in damp air would be higher than those discharged in dry air; as the spores would probably survive longer in damp than dry conditions.

The successive deterioration of $D$. procumbens shoots is shown in figure 3. It was observed that dried and dead populations of the moss were washed back into the stream at the onset of the following rainy season. This should be a source of nutrients to enrich the habitat. 


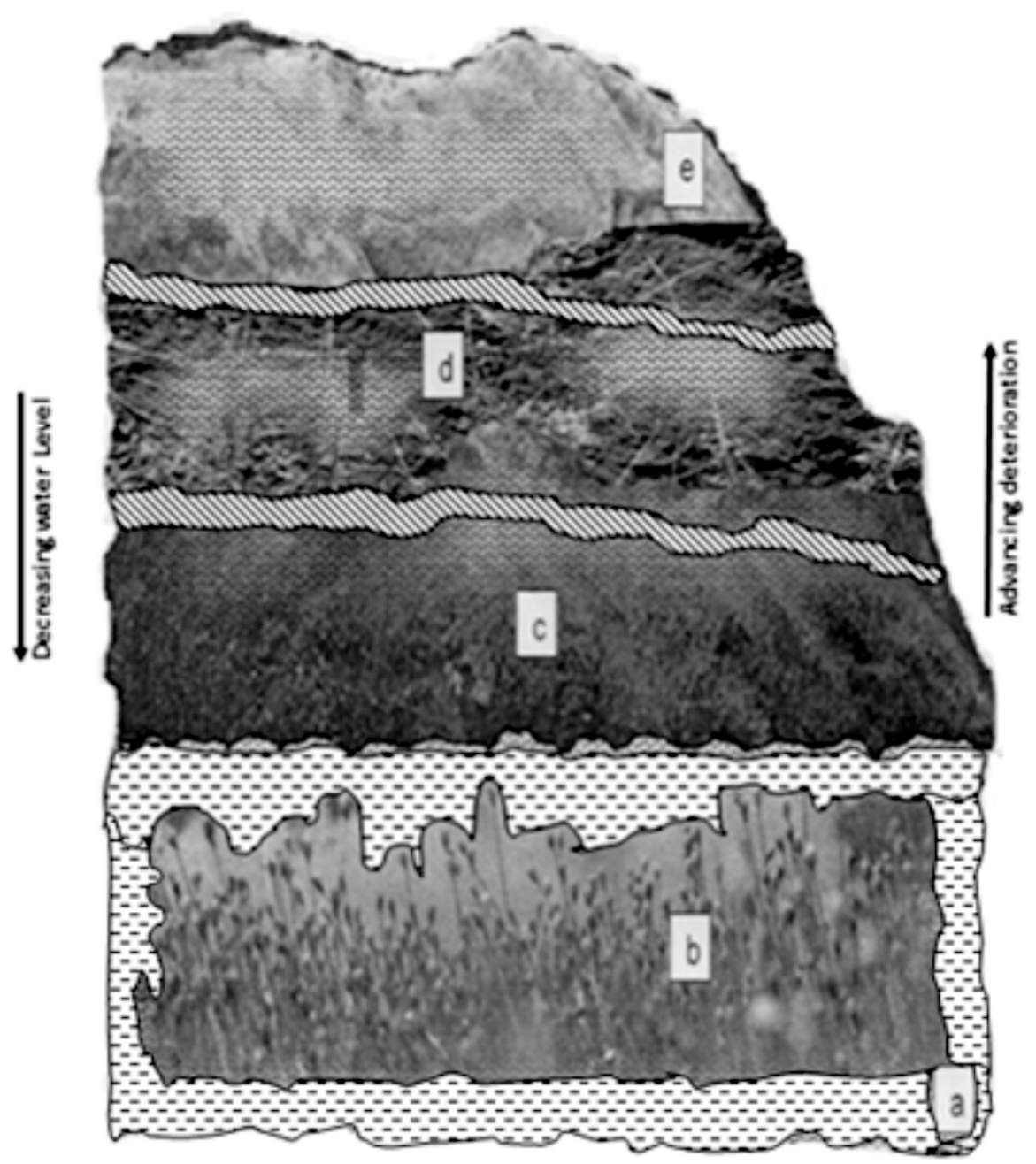

Figure 3: Successive deterioration of D. procumbens, (a) submerged granite rock surface (b), submerged mature species population (c) exposed species population in a drying state (d) advanced drying state showing networks of shoots (e), whitish-grey crust of dried species population.

\section{CONCLUSION}

The occurrence of Distichophyllum procumbens in Nigeria is reported for the first time. Although, the pleurocarp had been reported to be epixylic, corticolous, saxicolous and terricolous elsewhere in West Africa, it was found to be saxicolous secondarily-aquatic in Omee river, Ago-Iwoye, Nigeria. The moss was adapted to the rheophilous habitat by the stem "leaves" having borders and strong costae, both for strengthening against water current. Other adaptations include shoots turning reddish brown when exposed during the dry season, absence of a tomentum and occurrence of rhizoids only at the base of the stem. Aquatically adapted sporophyte features noted include aperistomate capsule (usually considered primitive), splitting vertically on dehiscence into valves for spore discharge and spore barrels surrounded with floater jackets. The observations reported in this work, will be very useful in undertaking detailed autecological field and laboratory studies of $D$. procumbens as an aquatic moss.

\section{ACKNOWLEDGEMENTS}

We thank Reuben Obasi (Garden assistant), Bayo Ojeleke and Joshua Ajowele (Undergraduate students) for their help in the collection of the plant samples during bryological forays.

\section{REFERENCES}

Braten, T. 1975. Observations on mechanisms of attachment in the green alga, Ulva mutabilis Foyn: An ultrastructural and lightmicroscopical study of zygotes and rhizoids. Protoplasm 84: 161-173. 
Buck W.R. and Goffinet B. 2000. Morphology and classification of mosses. In: Bryophyte Biology, ed. A.J. Shaw and B.Goffinet, pp. $71-123$. UK: Cambridge University Press.

Callow, M.E. and Evans, L.V. 1974. Studies on the ship-fouling alga, Enteromorpha III. Cytochemistry and autoradiography of adhesive production. Protoplasm 80:15-27.

Glime, J.M. 1971. Response of two species of Fontinalis to field isolation from stream water. Bryologist 74: 383-386.

Glime, J.M. 1980. Some northern calciphilic mosses in the Laurence Lake fen and marsh (Barry Co. Michigan). Michigan Botanist 19: 91-92.

Glime, J.M., Nissila, P.C., Trynoski, S.E. and Fornwall, M.D. 1979. A model for attachment of aquatic mosses. Journal of Bryology 10:313-320.

Glime, J.M. and Raeymaekers, G. 1987. Temperature effects on branch and rhizoid production in six species of Fontinalis. Journal of Bryology 14:770 - 790.

Glime, J. M. and Vitt, D.H. 1987. A comparison of bryophyte species diversity and niche structure of montane streams and stream banks. Canada Journal of Botany 65(9): 1824-1837

Ingold, C.T. 1959. Peristome teeth and spore discharge in mosses. Transaction of Botanical Society of Edinburgh 38: 76-88.

Odu, E.A. 1979 Observations on the distribution of rhizoids on shoots of pleurocarpous mosses. Journal of Bryology 10:287-289.

O'Shea, B.J. 2006. Checklist of the mosses of subsaharan Africa (version 5). Tropical Bryology Research Reports 6:1-252,

Magdefrau, K. 1973. Hydropogon fontinaloides ( $\left.\begin{array}{lllll}\mathrm{H} & \mathrm{O} & \mathrm{O} & \mathrm{k}\end{array}\right)$ Brideinpeiodischhydroaerophyytisches Laubmoos des Orinocos und Amazonas. Herzogia 3: 141 - 149.

Matteri, C.M. 1975. Bryophyta, Musci Hookeriales in Flora Criptogamica de tierradelfuego Argentina. Tomo XIV, fascicula 9.

Mclean, R.O. and Jones, A.K. 1975. Studies of tolerance to heavy metals in the flora of the rivers Ystwyth and Clarach, Wales. Freshwater Bioogy 5: 431 - 441 .

Miller, H.A. 1971. An overview of the Hookeriales. Phytologia 21(4):: 243-252.

Richards, P.W. and Edwards, S.R. 1972. Notes on African mosses - V. Journal of Bryology, 7 : $47-60$.

Richardson, D.H.S. 1981. The Biology of Mosses. Blackwell Scientific Publications, U.K. 220 pp.

Vitt, D.H. 1981. Adaptive modes of the moss sporophyte, The Bryologist, 84(2): 166 186.

Vitt, D.H. and Glime, J.M. 1984. The structural adaptations of aquatic Musci. Lindbergia, 10: $95-110$. 